\title{
A mortality study among mild steel and stainless steel welders
}

Jean J Moulin, Pascal Wild, Jean M Haguenoer, Dominique Faucon, Régis De Gaudemaris, Jean M Mur, Mathieu Mereau, Yves Gary, Jean P Toamain, Yves Birembaut, Marcel Blanc, Marie P Debiolles, Dominique Jegaden, Bernard Laterrière, Martine Léonard, François Marini, Christian Massardier, Martine Moulin, Michèle Reure, Lionel Rigal, Gérard Robert, Michel Viossat

\begin{abstract}
A mortality study was carried out in conjunction with the European mortality study among welders coordinated by the International Agency for Research on Cancer (IARC). The study was aimed at assessing risks for lung cancer in relation to exposure to asbestos, welding fumes containing chromium and nickel, and tobacco smoke. The study included a cohort of 2721 welders and an internal comparison group of 6683 manual workers employed in 13 factories in France. The mortality of the two cohorts was studied from 1975 to 1988 by the historical prospective method. Job histories of welders were traced including welding processes used, metals welded, and proportion of worktime spent in welding. Data on smoking habits were collected from medical records. The observed number of deaths were compared with those expected (standardised mortality ratio (SMR)) based on national rates with adjustments for age, sex,
\end{abstract}

Institut National de Recherche et de Sécurité, Service d'Epidémiologie, 54500 Vandoeuvre, France J J Moulin, P Wild, J M Mur, J P Toamain

Institut de Médecine du Travail du Nord, Place de

Verdun, 59045 Lille, France

J $M$ Haguenoer

Institute de Médicine du Travail de Saint Etienne, Hôpital Bellevue, 42000 Saint Etienne, France

D Faucon, $M$ Moulin

Institute de Médecine du Travail de Grenoble, Hôpital des Sablons, 38700 La Tronche, France

R De Gaudemaris

Caisse Régionale d'Assurance Maladie NordPicardie, 11 allée Vauban, 59661 Villeneuve d'Ascq, France

M Mereau

Caisse Régionale d'Assurance Maladie Rhône-Alpes, 24 rue d'Aubigny, 69436 Lyon, France

Y Gary

Occupational Physicians of the Industry

Y Birembaut, $M$ Blanc, $M P$ Debiolles, $D$ Jegaden, B Laterrière, $M$ Léonard, $F$ Marini, C Massardier, M Reure, L Rigal, G Robert, $M$ Viossat and calendar time. The smoking habits of $87 \%$ of the whole study population were known. The distribution of welders and controls according to smoking was not statistically different. The overall mortality was slightly higher for welders $(S M R=1.02,95 \%$ confidence interval $(95 \%$ CI) $0.89-1 \cdot 18)$ than for controls (SMR $=0.91,95 \%$ CI 0.84-0.99). For lung cancer, the SMR was 1.24 (95\% CI 0.75-1.94) for welders, whereas the corresponding value was lower for controls $(S M R=0.94,95 \%$ CI 0.681.26). The SMR for lung cancer was 1.59 among non-shipyard mild steel welders $(95 \%$ CI $0.73-$ 3.02). This contrasted with the results for all stainless steel welders (SMR $=0.92,95 \%$ CI 0.19-2.69), and for stainless steel welders predominantly exposed to chromium VI (SMR $=1 \cdot 03,95 \%$ CI 0.12-3.71). Moreover, SMRs for lung cancer for mild steel welders tended to increase with duration of exposure and time since first exposure, leading to significant excesses for duration $\geqslant 20$ years and latency $\geqslant 20$ years. Such a pattern was not found for stainless steel welders.

(British Journal of Industrial Medicine 1993;50:234-243)

Welding consists of several processes that result in occupational exposures to various substances. The content of welding fumes depends both on the metals welded and on the welding processes involved. ${ }^{12}$ In the case of stainless steel welding, unlike mild steel welding, the fumes contain nickel and chromium compounds, particularly chromium $\mathrm{VI}^{1-4}$ which have carcinogenic effects for humans under certain situations-namely, chromate production, chromate pigment production, chromium plating industries, and the nickel refining industry. ${ }^{1}$

To assess risk of lung cancer due to welding, several epidemiological studies have been carried out over the past 40 years. A recent paper ${ }^{5}$ has reviewed 14 case-control studies taking welding into account and 27 cohort studies. ${ }^{6-46}$ Only five of them reported 
relative risks below $1 \cdot 00,{ }^{6-10}$ whereas the other 36 pointed out a relation between lung cancer and welding. ${ }^{11-46}$ Of these, several (five case-control studies ${ }^{11-15}$ and 16 cohort studies ${ }^{16-31}$ ) reported relative risks ranging from 1.25 to 1.70 . Relative risks higher than 2.00 were found in nine studies. ${ }^{32-40}$ of the 36 studies considered, the results of only four case-control studies ${ }^{14333536}$ and 12 cohort studies $^{16-18232427283031383941 \quad \text { reached statistical }}$ significance.

A $30 \%$ to $40 \%$ increase in relative risk of lung cancer among welders is now a generally accepted figure. ${ }^{3547}$ Nevertheless, three questions remain unanswered with regard to the explanation of this moderate excess. It could be accounted for by a higher excess in the sub-group of stainless steel welders exposed to nickel and chromium compounds, under the assumption that stainless steel welders have risks for lung cancer similar to those found among workers exposed to the same compounds in the mentioned industries. ${ }^{13}$ Additional exposure to asbestos, particularly in shipyards, may have resulted in the occurrence of some lung cancer cases in excess. ${ }^{47}$ The carcinogenic effects of tobacco smoke may also have contributed to this excess as some previous studies have suggested that welders may smoke more than the general population. 4849

To investigate these three problems, the International Agency for Research on Cancer (IARC) initiated a mortality and cancer incidence study including 135 factories from eight European countries, of which France contributed five. The results concerning the European cohort along with those obtained in some countries have already been published. ${ }^{25}$ 29-31 41

The data collection in France was further extended for the present study both by incorporating new factories and by updating the follow up for the existing ones. Thus the present study is an extension of the French data that were included in the IARC study. ${ }^{41}$ Furthermore this study differs from that of the IARC because smoking habits are taken into account and an internal reference group is involved. The French study was initiated and conducted within the framework of collaboration coordinated by the National Institute for Research and Safety (INRS) and the Institute of Occupational Health of Lille, and includes the Institutes of Occupational Health of Grenoble and of St Etienne, along with the National Health Insurance Fund ("Caisse Nationale d'Assurance Maladie"), five regional health insurance funds ("Caisses Régionales d'Assurance Maladie"), and the French Ministry of Research and Technology.

\section{Materials and methods}

STUDY POPULATIONS

The data were collected from the personnel registers of 13 factories including three shipyards. Two cohorts were defined in each factory. The welding exposed cohort consisted of all male workers who were employed as welders at the date of beginning of the follow up period. For each welder, three controls (if possible) were selected at random among the nonwelders employed at this date. Due to the absence of non-welders, this selection was not possible in two factories that included $8.5 \%$ of the study population.

The cohorts were restricted to workers with at least one year of employment. Each control had to be a manual worker, and have never been employed as a painter, a foundry worker, a boilermaker, or a cutter. The internal comparison group was restricted in such a manner to avoid the potential lung cancer risks due to chromate paints, polycyclic aromatic hydrocarbons, silica, and welding fumes.

The personnel offices of the factories provided the name, date and place of birth, date of first employment, and date and reason for end of employment when applicable, for each subject.

\section{FOLLOW UP AND VITAL STATUS}

It was decided that the follow up would start in the 1970s, because most stainless steel welding activities started in the decade 1950-60, and because occupational lung cancer usually occurs 10 years or more after the beginning of exposure. These follow up periods differ slightly from factory to factory depending on the availability of data: they started in 1975 or in 1976 and they were extended up to 1987 or the end of 1988.

The vital status of the subjects was determined from information provided by the administrative records of the factories, by the registry office of the subjects' birthplaces, and by the national file of the French National Institute for Statistics and Economical Studies (INSEE). The vital status of foreigners was also ascertained from INSEE, except for those who died abroad whose deaths are not recorded. For this reason, foreigners were considered as still alive at the date of the end of the follow up for the calculation of person-years.

A total of 730 deaths were detected in the whole study population.

\section{CAUSES OF DEATHS}

The causes of deaths were ascertained through the French national file of causes of death managed by the French National Institute for Medical Research and Health (INSERM, Dr F Hatton, Mrs E Michel). This national file is anonymous and contains the codes of the International Classification of Diseases (ICD) so that names could not be used to identify the deaths in the study. Each subject had to be sought, matching on the three following items that appear in the national file: date of birth, date of death, and place of death. Thus these data were used for the linkage 
between the national file and the database of the study.

Due to incomplete data, or because more than one person in the national file satisfied the matching criteria, $7 \%$ of the causes of death could not be identified. These unknown causes of death were then ascertained from records of hospitals and of general practitioners. After this further investigation, the causes of deaths were available for $98 \%$ of the subjects.

\section{SMOKING HABITS}

The workers of French factories have to undergo an individual clinical examination by the occupational physician once a year, so that smoking habits throughout the working history are usually recorded. The smoking data collected for this study were abstracted from these medical records. The available items were the three smoking groups-namely, never, former, and current smokers; the last being subdivided into five groups: $\leqslant 5$ cigarettes day, 6-15 cigarettes day, $\geqslant 15$ cigarettes day, pipe-cigar, and unknown amount. As the complete smoking history was not available, no cumulative assessment of smoking could be done. As shown in table 1, the smoking habits were known for $86.6 \%$ of the whole study population $(86.6 \%$ of the welders and $86.5 \%$ of the controls). The percentage of known smoking habits varied from factory to factory, ranging from $61 \cdot 7 \%$ to $97 \cdot 1 \%$, depending on the completeness of medical records.

\section{EXPOSURE DATA ON WELDING FUMES}

Three factories, including 471 welders and 1388 controls, are shipyards. The materials most commonly used in these three factories are mild steel and low alloyed (chromium or nickel) steels, which are sometimes coated with antirust paints. Two other factories also work for the army, producing armoured military vehicles and tanks. Their main base materials are mild steel, stainless steel, armoured steels, and aluminium. The other factories produce different types of products for metallurgy, using mild steel, stainless steel, or aluminium as base materials.

The main welding techniques initially used in most factories were manual metal arc (MMA) welding and oxyacetylene welding to a lesser extent. Due to further technical developments which occurred in the industry, other welding processes have been introduced: tungsten inert gas (TIG), metal inert gas (MIG), and metal active gas (MAG). These last three processes along with MMA account for most of the welding activities encountered in this study. Other processes, such as oxyacetylene and plasma cutting, arc gouging and brazing, and submerged arc welding are more rarely used.

The welding activities include the metals welded, the welding processes involved, and the proportions of worktime spent in welding. They were taken into account for each welder since the date of first employment in the factory. This information on job histories was available at individual levels in eight factories, providing the successive periods of time corresponding to each welding activity carried out by each welder. In the other five factories, the individual data provided information only on the workshops where each welder had been successively employed. To assess individual exposures, details were then obtained on the welding activities in each workshop throughout the periods of employment of the welders. It was then assumed that all welders in a given workshop of a factory had done similar work at any given period of employment.

A similar heterogeneity in the data collection on job histories appeared in the European study carried out by the IARC and the same assumption was made with regard to the exposure assessment of the welders when individual data were not available. ${ }^{4}$ Subgroups of welders were then defined according to the job exposure matrix set up for the IARC study: ${ }^{4}(1)$

Table 1 Demographic data, job histories, and smoking habits of the study populations

\begin{tabular}{|c|c|c|}
\hline & Welders & Controls \\
\hline No of subjects & 2721 & 6683 \\
\hline Lost to follow up & $122(4 \cdot 5 \%)$ & $221(3 \cdot 3 \%)$ \\
\hline Person-years & 34131 & 84429 \\
\hline Average year of birth & 1940 & 1938 \\
\hline Average year first employed & 1965 & 1962 \\
\hline Average duration of employment $(y)$ & $19 \cdot 5$ & 21.9 \\
\hline Average year of death & 1983 (203 subjects) & 1982 (527 subjects) \\
\hline Known smoking habits (\%) & 86.8 & $86 \cdot 5$ \\
\hline Non-smokers $\star$ & $32 \cdot 3$ & $34 \cdot 7$ \\
\hline Former smokers $\star$ & $14 \cdot 1$ & $12 \cdot 8$ \\
\hline Current smokers ${ }^{\star}$ & $52 \cdot 7$ & $52 \cdot 5$ \\
\hline$\leqslant 5 \mathrm{~g} /$ day $^{\star}$ & $6 \cdot 3$ & $5 \cdot 5$ \\
\hline $6-15 \mathrm{~g} /$ day $^{\star}$ & $20 \cdot 3$ & $20 \cdot 0$ \\
\hline$\geqslant 15 \mathrm{~g} /$ day $^{\star}$ & $24 \cdot 1$ & $22 \cdot 2$ \\
\hline Únknown amount * & 1.8 & 4.5 \\
\hline Pipe-cigar ${ }^{\star}$ & $0 \cdot 1$ & $0 \cdot 3$ \\
\hline
\end{tabular}

$\star$ Percentage of subjects with known smoking habits. 
boilermakers and part time welders only, (2) mild steel welders only, (3) ever stainless steel welders, (4) welders predominantly exposed to chromium VI. The last category included welders for whom more than $70 \%$ of the welding activities had been, for at least one year, either MMA welding of stainless steel or MMA welding of armoured steel using stainless steel coated electrodes or oxyacetylene welding or cutting of stainless steel.

\section{ADDITIONAL EXPOSURES OF WELDERS AND CONTROLS}

Welders may be exposed to asbestos, either because of the use of individual protection devices such as gloves or blankets, or because of the presence of insulation materials in the working environment. The second exposure is likely to have occurred in shipyards. The information on exposure to asbestos was available at the factory level only, so that it was not relevant for the statistical analysis. The only way to account for the effects of asbestos was to separate shipyards from other factories. Furthermore, due to the possible presence of asbestos in the environment of the workplaces in shipyards, shipyard controls might also have been exposed to asbestos, which was another reason to carry out a separate analysis for shipyards.

In some factories, primers or paints might have been applied to minimise corrosion of steel during storage. The welding of such coated steels may have resulted in additional exposure to organic contaminants or to metals such as chromium, depending on the chemical composition of the paint. ${ }^{1}$ As for exposure to asbestos, this information was not available at individual levels so that the welding of coated steels could not be taken into account in the analysis.

\section{ANALYTICAL METHODS}

Standard methods as described by Breslow and Day ${ }^{50}$ were used to compute person-years at risk, expected numbers of causes of death, and ratios between observed and expected numbers (standardised mortality ratios (SMRs)), with the program written by Coleman et al. ${ }^{51}$ The observed numbers of deaths were assumed to follow the Poisson distribution and exact confidence intervals were computed for the SMR. For the welders as well as for the controls, person-years began at the beginning of the follow up period or once they had been employed for one year, whichever was later.

In the analyses by subgroups, person-years were assigned to the mild steel only group from the beginning of mild steel welding until end of follow up or until the first occurrence of stainless steel welding; person-years were assigned to the ever stainless steel group from the moment they had welded stainless steel until the end of follow up. In the same way person-years in the predominantly chromium VI group started as soon as this exposure began. Thus if a welder had, for example, been welding mild steel from 1970 to 1980 and stainless steel afterwards with a beginning of follow up in 1975 he contributed five years (from 1975 to 1979 ) to the mild steel only group and all the subsequent person-years to the ever stainless steel group. A small percentage of welders was excluded from this analysis by subgroups because of incomplete working histories.

Death certificates and causes of death collected from general practitioners were coded using the International Classification of Diseases (ICD) codes (8th revision from 1975 to 1978 and 9th revision from 1979 to 1988). The reference rates used to compute the expected numbers of deaths were the national rates for the male population subdivided by five year age groups and five year periods. Death rates of welders and controls were thus compared to rates of the French male population using analyses conducted according to duration of employment and time since first employment. Additional analyses were performed within the subgroups of welders using duration of exposure to welding and time since first exposure to welding. Furthermore, a five year lag period was introduced because exposures occurring shortly before death are unlikely to be the cause of cancer. All welding periods within five years of death or end of follow up were therefore excluded from consideration.

Relative risks comparing welders with controls were calculated by dividing the SMRs of welders by the SMR of non-welders. Significance was assessed using the binomial distribution as described by Breslow and Day. ${ }^{50}$ To be able to compare directly welders and non-welders without external reference rates, a Poisson model using the EGRET and GLIM software packages was fitted..$^{53}$

\section{Results}

DESCRIPTION OF THE STUDY POPULATION

Table 1 gives a description of the cohort of the welders compared with the control cohort. The follow up of 9404 workers was $96 \%$ successful and was similar between welders and controls. The comparison of the average year of birth shows that the matching procedure was nearly successful. The differences in year of first employment and in duration of employment are consistent with the year of birth and do not suggest any fundamental differences between the job histories of welders and nonwelders. The data on smoking habits showed that the welders had smoked slightly more than the controls (32.3 $v 34.7$ non-smokers and 24.1 $v 22.2$ heavy smokers). This difference was taken into account in the analysis of mortality by lung cancer with Axelson's indirect adjustment and in the Poisson modelling procedure. ${ }^{54}$

WELDERS AND CONTROLS

Table 2 gives the mortality results by cause of death for the two study cohorts and for all factories 
Table 2 SMRs and 95\% CIs for selected causes among 2721 welders and 6683 controls

\begin{tabular}{|c|c|c|c|c|c|c|c|c|}
\hline \multirow[b]{2}{*}{ Causes of death (ICD-8) } & \multicolumn{4}{|c|}{ Welders } & \multicolumn{4}{|c|}{ Controls } \\
\hline & $O b s$ & $\operatorname{Exp}^{\star}$ & $S M R$ & $(95 \% C I)$ & Obs & $\operatorname{Exp} p^{\star}$ & $S M R$ & $(95 \% C I)$ \\
\hline Circulatory system (390-459) & 47 & $43 \cdot 20$ & 1.09 & $(0 \cdot 80-1 \cdot 45)$ & 114 & $132 \cdot 83$ & 0.86 & $(0.71-1.03)$ \\
\hline Ischaemic heart diseases $(410-414)$ & 28 & 18.57 & 1.51 & $(1 \cdot 00-2 \cdot 18)$ & 52 & $57 \cdot 01$ & 0.91 & $(0.68-1 \cdot 20)$ \\
\hline Cerebrovascular diseases $(430-438)$ & 9 & $9 \cdot 71$ & 0.93 & $(0.42-1 \cdot 76)$ & 25 & $30 \cdot 01$ & 0.83 & $(0.54-1 \cdot 23)$ \\
\hline Respiratory system $(460-519)$ & 6 & $7 \cdot 32$ & 0.82 & $(0 \cdot 30-1 \cdot 78)$ & 20 & 22.63 & 0.88 & $(0.54-1.36)$ \\
\hline Cirrhosis of the liver (571) & 20 & $13 \cdot 39$ & 1.49 & $(0.91-2 \cdot 31)$ & 53 & $39 \cdot 14$ & $1 \cdot 35$ & $(1 \cdot 01-1 \cdot 77)$ \\
\hline Accidents and violence (800-999) & 35 & 36.64 & 0.96 & $(0.67-1.33)$ & 78 & $92 \cdot 73$ & 0.84 & $(0.66-1.05)$ \\
\hline Suicides (950-959) & 13 & $11 \cdot 71$ & $1 \cdot 11$ & $(0.59-1.90)$ & 25 & $29 \cdot 94$ & $0 \cdot 84$ & $(0.54-1 \cdot 23)$ \\
\hline Travel accidents $(810-829,846-848)$ & 10 & $10 \cdot 50$ & 0.95 & $(0 \cdot 46-1 \cdot 75)$ & 18 & $25 \cdot 35$ & 0.71 & $(0.42-1 \cdot 12)$ \\
\hline All malignant neoplasms $(140-208)$ & 60 & $64 \cdot 28$ & 0.93 & $(0 \cdot 71-1 \cdot 20)$ & 187 & $194 \cdot 21$ & 0.96 & $(0.83-1 \cdot 11)$ \\
\hline Buccal cavity, pharynx (140-149) & 6 & $7 \cdot 12$ & 0.84 & $(0 \cdot 31-1 \cdot 84)$ & 16 & $20 \cdot 80$ & 0.77 & $(0 \cdot 44-1 \cdot 25)$ \\
\hline Larynx (161) & 3 & $4 \cdot 46$ & 0.67 & $(0.14-1.97)$ & 15 & $13 \cdot 26$ & $1 \cdot 13$ & $(0.63-1.87)$ \\
\hline Oesophagus (150) & 4 & $5 \cdot 12$ & 0.78 & $(0 \cdot 21-2 \cdot 00)$ & 17 & $15 \cdot 36$ & $1 \cdot 11$ & $(0 \cdot 64-1 \cdot 77)$ \\
\hline Stomach (151) & 6 & $2 \cdot 87$ & 2.09 & $(0 \cdot 77-4 \cdot 55)$ & 12 & 8.90 & $1 \cdot 35$ & $(0 \cdot 70-2 \cdot 35)$ \\
\hline Liver (155) & 3 & $2 \cdot 31$ & $1 \cdot 30$ & $(0 \cdot 27-3 \cdot 79)$ & 10 & $7 \cdot 20$ & 1.39 & $(0.67-2 \cdot 55)$ \\
\hline Pancreas (157) & 0 & $2 \cdot 17$ & 0.00 & $(0 \cdot 00-1 \cdot 70)$ & 5 & 6.67 & 0.75 & $(0 \cdot 24-1 \cdot 75)$ \\
\hline All digestive cancers $(150-159)$ & 17 & $18 \cdot 52$ & 0.92 & $(0.53-1.47)$ & 56 & 56.96 & 0.98 & $(0 \cdot 74-1 \cdot 28)$ \\
\hline Lung (162) & 19 & $15 \cdot 33$ & $1 \cdot 24$ & $(0.75-1.94)$ & 44 & $46 \cdot 72$ & 0.94 & $(0.68-1 \cdot 26)$ \\
\hline Pleura (163) & 0 & 0.41 & 0.00 & $(0.00-8 \cdot 92)$ & 3 & $1 \cdot 25$ & $2 \cdot 40$ & $(0 \cdot 49-7 \cdot 01)$ \\
\hline Bone-sarcoma $(170-171)$ & 0 & 0.77 & 0.00 & $(0 \cdot 00-4 \cdot 79)$ & 2 & $2 \cdot 18$ & 0.92 & $(0 \cdot 11-3 \cdot 31)$ \\
\hline Prostate $(185)$ & 0 & $1 \cdot 77$ & 0.00 & $(0 \cdot 00-2 \cdot 09)$ & 6 & 6.05 & 0.99 & $(0 \cdot 36-2 \cdot 16)$ \\
\hline Bladder (188) & 1 & 1.53 & 0.65 & $(0.02-3.64)$ & 4 & $4 \cdot 86$ & 0.82 & $(0 \cdot 22-2 \cdot 11)$ \\
\hline Brain (191) & 0 & $1 \cdot 34$ & 0.00 & $(0 \cdot 00-2 \cdot 75)$ & 6 & $3 \cdot 82$ & 1.57 & $(0.58-3 \cdot 42)$ \\
\hline Hodgkin's lymphoma (200-203) & 2 & 1.96 & 1.02 & $(0 \cdot 12-3 \cdot 68)$ & 7 & $5 \cdot 64$ & $1 \cdot 24$ & $(0 \cdot 50-2 \cdot 55)$ \\
\hline Leukaemia $(204-208)$ & 2 & $1 \cdot 76$ & $1 \cdot 13$ & $(0 \cdot 14-4 \cdot 10)$ & 2 & $5 \cdot 01$ & 0.40 & $(0.05-1 \cdot 44)$ \\
\hline
\end{tabular}

ICD-8 = International Classification of Diseases, 8 th revision.

^The expected numbers were calculated using national death rates, with adjustment for sex, age, and calendar time.

combined. The overall mortality of welders was close to that expected (SMR $=1.02$ ) whereas a statistically significant deficit occurred for controls $(S M R=0.91)$. An opposite pattern was seen for mortality from ischaemic heart disease because an excess of borderline significance existed for welders $(\mathrm{SMR}=1.51)$ that contrasted with the lower result of controls (SMR $=0.91$ ), leading to a significant relative risk of 1.66 (95\% CI 1.01-2.68).

Welders and controls both showed low results for non-malignant respiratory diseases $(S M R=0.82$ and $S M R=0.88$ respectively) and for violent causes (SMR $=0.96$ and 0.84 respectively). With regard to cirrhosis of the liver, however, the SMRs were high and similar (1.49 and 1.35 respectively, the second reaching statistical significance).

The SMR for mortality from all cancer sites was close to unity both for welders $(0.93)$ and controls $(0 \cdot 96)$. There were non-significant excesses for stomach cancer (2.09 and 1.35 respectively) and for cancer of the liver (1.30 and 1.39 respectively). For lung cancer, the main focus of interest of this study, a slight and non-significant excess occurred for welders $(S M R=1.24)$, which contrasted with a slight deficit for controls (SMR $=0.94)$, and which led to a nonsignificant relative risk of 1.32 . Three deaths from pleural tumours occurred in the control cohort, giving a non-significant excess of 2.40 . These three deaths occurred in workers from shipyards, so that the SMR was significantly above 1.00 (SMR = $3 / 0.26=11.54, \mathrm{p}<0.01)$ in these three factories. This result suggests that exposure to asbestos is likely to have occurred in the shipyards of the present study. Although no death from mesothelioma occurred among shipyard welders, the possibility of exposure of welders to asbestos could not be discarded as the expected number was 0.09 , indicating that the statistical power did not enable such a risk to be detected among welders.

Table 3 provides further data for selected causes of death, comparing both welders and controls to the French population. These cohorts can actually be compared using two measures that can be determined for welders and controls-namely, the duration of employment and time since first employment. Boundaries were chosen before the statistical analysis. An increasing trend occurred for the overall mortality with duration of employment among welders, which contrasted with the opposite pattern among controls. The same was found for time since first employment. There were similar results for mortality from ischaemic heart diseases and cirrhosis. No clear pattern occurred among welders and controls for non-malignant respiratory diseases and lung cancer. This lack of trend, however, could be partly due to small expected numbers in some categories.

The direct comparison between welders and con- 
Table 3 SMRs for selected causes among welders and controls by duration of employment and by time since first employment

\begin{tabular}{|c|c|c|c|c|c|c|}
\hline \multirow[b]{2}{*}{ Causes of death (ICD-8) } & \multicolumn{3}{|c|}{ Welders } & \multicolumn{3}{|c|}{ Controls } \\
\hline & Obs & $S M R^{\star}$ & p Value & Obs & $S M R^{\star}$ & p Value \\
\hline & \multicolumn{6}{|c|}{ Duration of employment } \\
\hline \multicolumn{7}{|l|}{ All causes (000-999): } \\
\hline$<10$ years & 17 & 0.72 & NS & 55 & $1 \cdot 03$ & NS \\
\hline $10-19$ years & 40 & $0 \cdot 78$ & NS & 126 & 0.94 & NS \\
\hline$\geqslant 20$ years & 146 & $1 \cdot 18$ & $p=0.05$ & 346 & $0 \cdot 89$ & $\mathrm{p}<0.05$ \\
\hline \multicolumn{7}{|c|}{ Ischaemic heart diseases $(410-414)$ : } \\
\hline $\begin{array}{l}<10 \text { years } \\
10-19 \text { years }\end{array}$ & $\begin{array}{l}0 \\
4\end{array}$ & $\begin{array}{l}0.00 \\
1.00\end{array}$ & $\begin{array}{l}\text { NS } \\
\text { NS }\end{array}$ & $\begin{array}{l}4 \\
7\end{array}$ & $\begin{array}{l}1.27 \\
0.63\end{array}$ & $\begin{array}{l}\text { NS } \\
\text { NS }\end{array}$ \\
\hline$\geqslant 20$ years & 24 & $1 \cdot 79$ & $\mathrm{p}<0.05$ & 41 & 0.96 & NS \\
\hline \multicolumn{7}{|c|}{ Respiratory system (460-519): } \\
\hline$<10$ years & 0 & 0.00 & NS & 0 & $0 \cdot 00$ & NS \\
\hline $10-19$ years & 4 & $2 \cdot 62$ & NS & 1 & $0 \cdot 23$ & NS \\
\hline$\geqslant 20$ years & 2 & $0 \cdot 38$ & NS & 19 & $1 \cdot 12$ & NS \\
\hline \multicolumn{7}{|l|}{ Cirrhosis (571): } \\
\hline$<10$ years & 1 & 0.64 & NS & 6 & $1 \cdot 52$ & NS \\
\hline $10-19$ years & 2 & 0.58 & NS & 15 & 1.55 & NS \\
\hline$\geqslant 20$ years & 17 & $2 \cdot 03$ & $\mathrm{p}<0.05$ & 32 & $1 \cdot 25$ & NS \\
\hline \multicolumn{7}{|l|}{ Lung cancer (162): } \\
\hline$<10$ years & 1 & $1 \cdot 19$ & NS & 0 & 0.00 & NS \\
\hline \multirow{3}{*}{$\begin{array}{r}10-19 \text { years } \\
\geqslant 20 \text { years }\end{array}$} & 2 & 0.63 & NS & 11 & $1 \cdot 23$ & NS \\
\hline & 16 & $1 \cdot 41$ & NS & 33 & 0.93 & NS \\
\hline & \multicolumn{6}{|c|}{ Time since first employment } \\
\hline \multicolumn{7}{|l|}{ All causes (000-999): } \\
\hline$<10$ years & 24 & $0 \cdot 76$ & NS & 73 & $1 \cdot 04$ & NS \\
\hline $10-19$ years & 45 & $0 \cdot 89$ & NS & 131 & 0.90 & NS \\
\hline$\geqslant 20$ years & 134 & $1 \cdot 15$ & NS & 323 & $0 \cdot 89$ & $\mathrm{p}=0.05$ \\
\hline \multicolumn{7}{|c|}{ Ischaemic heart diseases $(410-414)$ : } \\
\hline$<10$ years & 1 & 0.55 & NS & 4 & 0.89 & NS \\
\hline $10-19$ years & 4 & 0.95 & NS & 9 & 0.68 & NS \\
\hline$\geqslant 20$ years & 23 & $1 \cdot 84$ & $p<0.05$ & 39 & 0.99 & NS \\
\hline \multicolumn{7}{|c|}{ Respiratory system (460-519): } \\
\hline$<10$ years & 0 & 0.00 & NS & 0 & 0.00 & NS \\
\hline $10-19$ years & 4 & $2 \cdot 44$ & NS & 1 & $0 \cdot 19$ & NS \\
\hline$\geqslant 20$ years & 2 & 0.41 & NS & 19 & $1 \cdot 23$ & NS \\
\hline \multicolumn{7}{|l|}{ Cirrhosis (571): } \\
\hline$<10$ years & 1 & 0.86 & NS & 5 & 1.64 & NS \\
\hline $10-19$ years & 2 & 0.58 & NS & 13 & $1 \cdot 42$ & NS \\
\hline$\geqslant 20$ years & $1 \overline{7}$ & 1.94 & $\mathrm{p}<0.05$ & 35 & $1 \cdot 30$ & NS \\
\hline \multicolumn{7}{|l|}{ Lung cancer (162): } \\
\hline$<10$ years & 1 & $0 \cdot 75$ & NS & 1 & $0 \cdot 30$ & NS \\
\hline $10-19$ years & 3 & 0.90 & NS & 13 & $1 \cdot 25$ & NS \\
\hline$\geqslant 20$ years & 15 & $1 \cdot 41$ & NS & 30 & 0.91 & NS \\
\hline
\end{tabular}

*The expected numbers were calculated using national death rates, with adjustment for sex, age, and calendar time.

trols by Poisson regression showed that after adjustment for age, the rate ratio for lung cancer mortality was 1.29 (non-significant), similar to the ratio of SMRs (1.32).

\section{WELDING ACTIVITIES}

As mentioned, welders have been divided into four groups whose results are given in table 4 with a five year lag period. The overall SMRs were slightly lower for the two groups of stainless steel welders than for the other two categories of welders. Similarly, no excess was found among stainless steel welders compared with mild steel or part time welders for mortality due to non-malignant respiratory disease or to lung cancer. For ischaemic heart diseases, however, SMRs were high and similar among the four groups.
Table 5 provides the results of mortality from lung cancer with a five year lag period, according to duration of exposure and time since first employment as a welder. Due to possible exposure to asbestos in shipyards, these factories have been analysed separately. The highest lung cancer SMR was found for mild steel welders (SMR = 1.59), with lower values for shipyard welders $(S M R=0.91)$, part time welders, and boilermakers $(S M R=1 \cdot 14)$, and for the two groups of stainless steel welders $(S M R=0.92$ and $S M R=1.03)$. When taking into account duration of exposure and latency, although the numbers involved were limited, a statistically significant excess mortality from lung cancer was found for mild steel welders with more than 20 years of exposure and more than 20 years of latency. The SMRs were 3.24 and 2.42 respectively. It is worth 
Table 4 SMRs and 95\% CIs for selected causes among controls and sub-groups of welders including shipyard welders (five year lag)

\begin{tabular}{|c|c|c|c|c|c|c|c|c|}
\hline \multirow[b]{2}{*}{ Causes of death ( ICD-8) } & \multicolumn{4}{|c|}{ All causes (ICD-8000-999) } & \multicolumn{4}{|c|}{ Ischaemic heart diseases (ICD-8410-414) } \\
\hline & Obs & $\operatorname{Exp} p^{\star}$ & $S M R$ & $(95 \% C I)$ & Obs & $\operatorname{Exp} \star$ & $S M R$ & $(95 \% C I)$ \\
\hline $\begin{array}{l}\text { Controls } \\
\text { Part time welders only or boilermakers only } \\
\text { Mild steel welders only } \\
\text { Ever stainless steel welders } \\
\text { Predominantly chromium VI† }\end{array}$ & $\begin{array}{r}527 \\
42 \\
110 \\
45 \\
19\end{array}$ & $\begin{array}{r}577 \cdot 16 \\
36 \cdot 72 \\
96 \cdot 22 \\
54 \cdot 12 \\
23 \cdot 33\end{array}$ & $\begin{array}{l}0 \cdot 91 \\
1 \cdot 14 \\
1 \cdot 14 \\
0 \cdot 83 \\
0 \cdot 81\end{array}$ & $\begin{array}{l}(0.84-0.99) \\
(0.82-1.55) \\
(0.94-1.38) \\
(0.61-1.11) \\
(0.49-1.27)\end{array}$ & $\begin{array}{r}52 \\
5 \\
14 \\
9 \\
4\end{array}$ & $\begin{array}{r}57 \cdot 01 \\
3 \cdot 34 \\
9 \cdot 33 \\
5 \cdot 25 \\
2 \cdot 24\end{array}$ & $\begin{array}{l}0 \cdot 91 \\
1 \cdot 50 \\
1 \cdot 50 \\
1 \cdot 71 \\
1 \cdot 78\end{array}$ & $\begin{array}{l}(0.68-1 \cdot 20) \\
(0.49-3 \cdot 49) \\
(0 \cdot 82-2 \cdot 52) \\
(0 \cdot 78-3 \cdot 25) \\
(0.49-4 \cdot 56)\end{array}$ \\
\hline
\end{tabular}

^Expected numbers were calculated using national death rates, with adjustment for sex, age, and calendar time.

†Included in "ever stainless steel welders."

noticing that no such pattern occurred among stainless steel welders (the three observed cases had less than 10 years of exposure) or in the subgroup of stainless steel welders predominantly exposed to chromium VI.

\section{Discussion}

This study was set up in 1985 when the IARC started to coordinate the European mortality and cancer incidence study. Although the observed number of deaths is limited because of the shortness of the follow up period, the French study is of interest because (1) an attempt was made to separate mild steel welders from stainless steel welders, (2) the smoking habits of nearly $87 \%$ of the study population are known so that this major confounding factor can be taken into account in the statistical analysis, (3) an internal comparison group was used, as was done in previous studies. ${ }^{10212543}$ The last method enabled control for the healthy worker effect and other non-occupational factors-namely, socioeconomic category and geographical factors that can affect the occurrence of lung cancer.

\section{SMOKING HABITS}

Our data indicate that welders had a non-significant excess of lung cancer when compared with controls (relative risk $=1.32$ ). This raises the question of whether or not this result could be accounted for by smoking habits, because welders smoked slightly more than controls (table 1 ).

To assess the excess of lung cancer due to smoking alone, a crude adjustment was made using the method already proposed. ${ }^{54} 55$ According to previously published results, ${ }^{56}$ the four different risk levels of $1.00,2.00,9.00$ and 15.00 were assumed respectively for non-smokers, smokers of $\leqslant 5 \mathrm{~g} /$ day, smokers of $6-15 \mathrm{~g} /$ day and smokers of $\geqslant 15 \mathrm{~g} /$ day. This method indicates that the tobacco overconsumption would lead to a $6 \%$ lung cancer excess among welders $v$ controls. This level of risk is noticeably lower than the $32 \%$ excess obtained by the comparison of SMRs or than the $29 \%$ excess observed using the Poisson regression.

Despite the fact that this method does not take into account the duration of smoking, it can be stated that the lung cancer excess in welders $v$ controls in the present study is unlikely to be explained by different smoking habits between these two groups.

\section{EXPOSURE TO ASBESTOS}

Asbestos is the other possible factor that needs to be discussed with regard to mortality from lung cancer. Due to the lack of individual data, exposure to asbestos cannot be directly taken into account in the analysis. An indirect assessment, however, can be attempted using mortality from lung cancer according to smoking habits, given the well known synergism between asbestos and smoking on the risk of lung cancer. ${ }^{57}$

Table 6 provides the results of mortality from lung cancer according to smoking habits. As expected, when compared with the French population, significant excesses were found among heavy smokers in all factories and among welders (SMR $=3.21$ ) as well as among controls $(S M R=2 \cdot 64)$. Also, due to the fact that the French population contains many smokers, low SMRs appeared among non-smokers. When considering shipyards separately, where asbestos exposure is likely to have occurred, SMRs were remarkably high among heavy smokers, for welders $(S M R=6.94, N S)$ and for controls $(S M R=5.07, p<0.01)$. These two results contrast with those found for heavy smokers in other factories, $(2.73(\mathrm{p}=0.05)$ and $2.13(\mathrm{p}<0.05)$ respectively).

These different patterns for shipyards and nonshipyard factories, along with the high SMR for mortality from mesothelioma among shipyard controls $(\mathrm{SMR}=11.54, \mathrm{p}<0.01)$ suggest that exposure to asbestos had probably been higher in shipyards than in other factories. It could therefore be suggested that the excess of lung cancer in nonshipyard mild steel welders ( $\mathrm{SMR}=1.59$, table 5$)$ is probably not attributable to exposure to asbestos.

\section{EXPOSURE TO WELDING}

The overall mortality of welders did not differ from that expected $(S M R=1.02)$ whereas a significant deficit was seen for controls $(S M R=0.91, p<0.05$ ) (table 2). Moreover, the SMRs of welders for all 


\begin{tabular}{|c|c|c|c|c|c|c|c|}
\hline \multicolumn{4}{|c|}{ Respiratory system ( ICD-8 460-519) } & \multicolumn{4}{|c|}{ Lung cancer ( ICD-8 162) } \\
\hline Obs & $\operatorname{Exp} p^{\star}$ & $S M R$ & $(95 \% C I)$ & Obs & $\operatorname{Exp} p^{\star}$ & $S M R$ & $(95 \% C I)$ \\
\hline $\begin{array}{r}20 \\
1 \\
j \\
0 \\
0\end{array}$ & $\begin{array}{r}22.63 \\
1.36 \\
3.63 \\
2.01 \\
0.85\end{array}$ & $\begin{array}{l}0.88 \\
0.74 \\
0.83 \\
0.00 \\
0.00\end{array}$ & $\begin{array}{l}(0.54-1 \cdot 36) \\
(0.02-4 \cdot 10) \\
(0 \cdot 17-2 \cdot 41) \\
(0.00-1.83) \\
(0.00-4.34)\end{array}$ & $\begin{array}{r}44 \\
4 \\
10 \\
5 \\
2\end{array}$ & $\begin{array}{r}46 \cdot 72 \\
2 \cdot 69 \\
7 \cdot 71 \\
4 \cdot 48 \\
1 \cdot 95\end{array}$ & $\begin{array}{l}0.94 \\
1.49 \\
1 \cdot 30 \\
1 \cdot 12 \\
1.03\end{array}$ & $\begin{array}{l}(0.68-1.26) \\
(0.41-3.81) \\
(0.62-2.38) \\
(0.36-2.61) \\
(0.12-3.71)\end{array}$ \\
\hline
\end{tabular}

Table 5 Lung cancer mortality for shipyard and subgroups of non-shipyard welders, by duration of exposure to welding and time since first exposure to welding (five year lag period)

\begin{tabular}{|c|c|c|c|c|c|c|}
\hline & \multicolumn{3}{|c|}{ Duration of exposure } & \multicolumn{3}{|c|}{ Time since first exposure } \\
\hline & Obs/exp & $S M R$ & $(95 \% C I)$ & $O b s / \exp$ & $S M R$ & $(95 \% C I)$ \\
\hline \multicolumn{7}{|c|}{ Shipyards welders: ${ }^{\star}$} \\
\hline Total & $3 / 3 \cdot 28$ & 0.91 & $(0 \cdot 19-2 \cdot 67)$ & & & \\
\hline$<20$ years & $2 / 1.25$ & 1.60 & $(0 \cdot 19-5 \cdot 78)$ & $2 / 0 \cdot 60$ & 3.33 & $(0 \cdot 40-12 \cdot 03)$ \\
\hline$\geqslant 20$ years & $1 / 2 \cdot 03$ & 0.49 & $(0.01-2 \cdot 74)$ & $1 / 2 \cdot 68$ & $0 \cdot 37$ & $(0.01-2 \cdot 08)$ \\
\hline \multicolumn{7}{|c|}{ Part time welders, boilermarkers: ${ }^{\dagger}$} \\
\hline Total & $3 / 2 \cdot 63$ & $1 \cdot 14$ & $(0 \cdot 24-3 \cdot 33)$ & & & \\
\hline$<20$ years & $0 / 1 \cdot 67$ & 0.00 & $(0 \cdot 00-2 \cdot 21)$ & $0 / 1 \cdot 11$ & 0.00 & $(0 \cdot 00-3 \cdot 32)$ \\
\hline$\geqslant 20$ years & $3 / 0.96$ & $3 \cdot 11$ & $(0 \cdot 64-9 \cdot 10)$ & $3 / 1.52$ & 1.97 & $(0 \cdot 41-5 \cdot 77)$ \\
\hline \multicolumn{7}{|c|}{ Mild steel welders only: ${ }^{+}$} \\
\hline Total & $9 / 5 \cdot 65$ & 1.59 & $(0.73-3.02)$ & & & \\
\hline$<20$ years & $4 / 4 \cdot 11$ & 0.97 & $(0 \cdot 26-2 \cdot 49)$ & $1 / 2 \cdot 36$ & 0.42 & $(0 \cdot 01-2 \cdot 36)$ \\
\hline$\geqslant 20$ years & $5 / 1.54$ & $3 \cdot 24$ & $(1.05-7.55)$ & $8 / 3 \cdot 30$ & $2 \cdot 42$ & $(1 \cdot 05-4 \cdot 78)$ \\
\hline \multicolumn{7}{|c|}{ Ever stainless steel welders: ${ }^{\dagger}$} \\
\hline Total & $3 / 3 \cdot 26$ & 0.92 & $(0 \cdot 19-2 \cdot 69)$ & & & \\
\hline$<20$ years & $3 / 2 \cdot 79$ & 1.08 & $(0 \cdot 22-3 \cdot 14)$ & $2 / 1.66$ & $1 \cdot 20$ & $(0 \cdot 14-4 \cdot 35)$ \\
\hline$\geqslant 20$ years & $0 / 0 \cdot 47$ & 0.00 & $(0.00-7 \cdot 82)$ & $1 / 1 \cdot 60$ & 0.63 & $(0.02-3 \cdot 49)$ \\
\hline \multicolumn{7}{|c|}{ Predominantly chromium VI: ${ }_{+}^{+}$} \\
\hline Total & $2 / 1.95$ & 1.03 & $(0 \cdot 12-3 \cdot 71)$ & & & \\
\hline$<20$ years & $2 / 1 \cdot 71$ & $1 \cdot 17$ & $(0 \cdot 14-4 \cdot 22)$ & $1 / 0.93$ & 1.08 & $(0.03-5.99)$ \\
\hline$\geqslant 20$ years & $0 / 0 \cdot 23$ & 0.00 & $(0 \cdot 00-15 \cdot 85)$ & $1 / 1 \cdot 01$ & 0.99 & $(0.03-5 \cdot 51)$ \\
\hline
\end{tabular}

«Part time welders and boilermakers not included.

†Non-shipyard welders.

†Included in ever stainless steel welders.

Table 6 Lung cancer mortality according to smoking among welders and controls employed in shipyards and in other factories

\begin{tabular}{|c|c|c|c|c|c|c|}
\hline & \multicolumn{3}{|c|}{ Welders } & \multicolumn{3}{|c|}{ Controls } \\
\hline & Obs & $S M R$ & p Value & Obs & $S M R$ & p Value \\
\hline \multicolumn{7}{|l|}{ All factories: } \\
\hline Non-smokers & 2 & 0.54 & NS & 2 & $0 \cdot 14$ & $\mathrm{p}<0.001$ \\
\hline Current $\leqslant 5$ cigarettes/day & 0 & 0.00 & NS & 0 & 0.00 & NS \\
\hline Current $6-15$ cigarettes/day & 1 & $0 \cdot 36$ & NS & 9 & $1 \cdot 24$ & NS \\
\hline Current $\geqslant 15$ cigarettes/day & 8 & $3 \cdot 21$ & $\mathrm{p}<0.01$ & 21 & 2.64 & $\mathrm{p}<0.001$ \\
\hline \multicolumn{7}{|l|}{ Shipyards: } \\
\hline Non-smokers & 0 & 0.00 & NS & 0 & 0.00 & NS \\
\hline Current $\leqslant 5$ cigarettes/day & 0 & 0.00 & NS & 0 & 0.00 & NS \\
\hline Current $6-15$ cigarettes/day & 0 & 0.00 & NS & 1 & $0 \cdot 70$ & NS \\
\hline Current $\geqslant 15$ cigarettes/day & 2 & 6.94 & NS & 7 & 5.07 & $\mathrm{p}<0.01$ \\
\hline \multicolumn{7}{|l|}{ Non-shipyards: } \\
\hline Non-smokers & 2 & 0.65 & NS & 2 & $0 \cdot 16$ & $\mathrm{p}<0.001$ \\
\hline Current $\leqslant 5$ cigarettes/day & 0 & 0.00 & NS & $\overline{0}$ & 0.00 & NS \\
\hline Current $6-15$ cigarettes/day & 1 & 0.42 & NS & 8 & $1 \cdot 38$ & NS \\
\hline Current $\geqslant 15$ cigarettes/day & 6 & $2 \cdot 73$ & $p=0.05$ & 14 & $2 \cdot 13$ & $\mathrm{p}<0.05$ \\
\hline
\end{tabular}

causes of death tended to increase with duration of employment and with time since first employment whereas controls were opposite (table 3 ). The interpretation of this difference in terms of occupational risk is unclear, as it occurred particularly in the case of ischaemic heart diseases and cirrhosis.
Also, the significant excess of mortality from ischaemic heart disease among welders compared with controls is difficult to interpret because such a risk has never been previously reported. For this reason, although the result was statistically significant, it could still be due to chance. 
Table 7 Overall mortality and lung cancer mortality: comparison of results of the present French study with those previously found in the European study $y^{31}$

\begin{tabular}{|c|c|c|c|c|c|c|}
\hline & \multicolumn{3}{|c|}{ European study } & \multicolumn{3}{|c|}{ French study } \\
\hline & Obs & $S M R$ & $(95 \% C I)$ & Obs & $S M R$ & $(95 \% C I)$ \\
\hline \multirow{6}{*}{$\begin{array}{l}\text { Total welders } \\
\text { Shipyard welders } \\
\text { Mild steel only } \\
\text { Ever stainless steel } \\
\text { Predominantly stainless steel } \\
\text { Predominantly chromium VI }\end{array}$} & \multicolumn{6}{|c|}{ All causes (ICD-8000-999) } \\
\hline & \multirow{5}{*}{$\begin{array}{r}1093 \\
405 \\
287 \\
335 \\
212\end{array}$} & \multirow{5}{*}{$\begin{array}{l}0.93 \\
1.00 \\
1.01 \\
0.86 \\
0.84\end{array}$} & \multirow{5}{*}{$\begin{array}{c}(0.87-0.98) \\
(0.91-1.10) \\
(0.90-1.13) \\
(0.77-0.96) \\
(0.73-0.96)\end{array}$} & 203 & 1.02 & $(0 \cdot 89-1 \cdot 18)$ \\
\hline & & & & 48 & 1.23 & $(0 \cdot 91-1 \cdot 64)$ \\
\hline & & & & $\begin{array}{l}76 \\
31\end{array}$ & $\begin{array}{l}1.06 \\
0.77\end{array}$ & $(0.84-1.33)$ \\
\hline & & & & & & \\
\hline & & & & 19 & $0 \cdot 81$ & $(0 \cdot 49-1 \cdot 27)$ \\
\hline \multirow{6}{*}{$\begin{array}{l}\text { Total welders } \\
\text { Shipyard welders } \\
\text { Mild steel only } \\
\text { Ever stainless steel } \\
\text { Predominantly stainless steel` } \\
\text { Predominantly chromium VI }\end{array}$} & \multirow{6}{*}{$\begin{array}{r}116 \\
36 \\
40 \\
39 \\
20\end{array}$} & \multirow{6}{*}{$\begin{array}{l}1.34 \\
1.26 \\
1.78 \\
1.28 \\
1.23\end{array}$} & \multicolumn{2}{|c|}{ Lung cancer (ICD-8162) } & & \\
\hline & & & $(1 \cdot 10-1 \cdot 60)$ & 19 & $1 \cdot 24$ & $(0 \cdot 75-1 \cdot 94)$ \\
\hline & & & $(0 \cdot 88-1 \cdot 74)$ & 3 & 0.91 & $(0 \cdot 19-2 \cdot 67)$ \\
\hline & & & $(1.27-2.43)$ & 9 & 1.59 & $(0.73-3.02)$ \\
\hline & & & $\begin{array}{l}(0.91-1.75) \\
(0.75-1.90)\end{array}$ & 3 & 0.92 & $(0 \cdot 19-2 \cdot 69)$ \\
\hline & & & & 2 & 1.03 & $(0 \cdot 12-3 \cdot 71)$ \\
\hline
\end{tabular}

^Included in ever stainless steel welders.

When compared with the French population, stainless steel welders had SMRs slightly lower than those of mild steel welders for all causes of death (table 4). This was also the case in the European study, the only previous study that has been able to separate mild steel from stainless steel welders, as the authors have reported SMRs significantly below 1.00 for all causes of death among stainless steel welders (table 7) ${ }^{31}$ For lung cancer in the present study, the highest SMR was for mild steel welders $(\mathrm{SMR}=1.59)$ whereas the lowest values were for whole stainless steel welders $(S M R=0.92)$ and for stainless steel welders predominantly exposed to chromium VI (SMR = 1.03) (table 5, 7). Due to the small numbers, none of these results reached statistical significance, except for mild steel welders having more than 20 years of exposure and more than 20 years since first exposure. Consequently no firm conclusion could be drawn from this study alone. Nevertheless, the European study showed similar results with the highest lung cancer SMR obtained for mild steel welders $(S M R=1.78, p<0.05)$, the corresponding values being lower for ever stainless steel welders ( $S M R=1 \cdot 28$ ) and for predominantly stainless steel welders $(\mathrm{SMR}=1 \cdot 23)$, $($ table 7$){ }^{31}$

Two further comments can be made from the present study. Firstly, it has been shown that the excess of lung cancer among welders in comparison with controls (relative risk $=1.32$ ) might not be due to smoking as the excess attributable to smoking was about $1 \cdot 06$. Secondly, the comparison of lung cancer SMRs of heavy smokers among shipyard and nonshipyard workers suggests that the excess of lung cancer among non-shipyard mild steel welders $(\mathrm{SMR}=1.59)$ is unlikely to be explained by exposure to asbestos. If these two assumptions are accurate, the lung cancer excess found among mild steel welders remains unexplained.

The conclusion drawn by the authors of the
European study, however, was slightly different. Due to the fact that smoking habits were unknown and that there was a significant excess of mesothelioma, it has been suggested that smoking, or exposure to asbestos, or both might have contributed to the excess of lung cancer. ${ }^{31}$

On the whole, it can be concluded from the present study that the statistical analysis failed to show that risk for lung cancer is higher for stainless steel welders than for mild steel welders. The same conclusion was drawn in the IARC monograph on welding when reviewing the European study: "a large European study ... demonstrated no consistent difference in cancer risk among stainless steel welders as compared to mild steel welders or to shipyard welders." These conclusions disagree with those previously published by Becker $e \mathrm{al}^{25}$ and by Sjogren et $a l,^{3841}$ which suggested high risk of lung cancer for stainless steel welders.

Requests for reprints to: Dr J J Moulin, INRS, Avenue de Bourgone, BP 27, 54501 Vandoeuvre cedex, France.

1 International Agency for Research on Cancer. IARC Monographs on the evaluation of carcinogenic risks to humans. Chromium, nickel and welding fumes. Lyon: IARC, 1990. (Monograph No 49.)

2 Stern RM, Berlin A, Fletcher A, Hemminki K, Jarvisalo J, Peto $\mathrm{J}$. International conference on health hazards and biological effects of welding fumes and gases. Summary report. Int Arch Occup Environ Health 1986;57:237-46.

3 Stern RM. Assessment of risk of lung cancer for welders. Arch Environ Health 1983;38:148-55.

4 Simonato L, Winkelmann R, Ferro G, Saracci R, Charnay N. Report of a mortality and cancer incidence follow-up of an historical cohort of European welders. Lyon: International Agency for Research on Cancer, 1989. (IARC internal report 89/003.)

5 Moulin JJ, Diebold F, Limasset JC. Le risque de cancer chez les soudeurs: revue bibliographique des enquêtes épidémiologiques. Cahier des Notes Documentaires, INRS, Paris, 1991;145.

6 Blot WJ, Harrington JM, Toledo A, Hoover R, Heath CW, Fraumeni JF. Lung cancer after employment in shipyards during world war II. N Engl J Med 1978;299:620-4. 
7 Decoufle P, Stanislawczyk K, Houten L, Bross J, Viadana E. Retrospective survey of cancer in relation to occupation. Cincinnati: National Institute for Occupational Safety and Health, 1978. (No HSM 77-178.)

8 Ott MG, Holder BB, Langner RR. Determinants of mortality in an industrial population. J Occup Med 1976;18:171-7.

9 Peterson GR, Milham JS. Occupational mortality in the state of California 1969-1971. Cincinnati: National Institute for Occupational Safety and Health, 1980. (Publ No 80104.)

10 Steenland K, Beaumont J, Eliot L. Lung cancer in mild steel welders. Am J Epidemiol 1991;133:220-9.

11 Blot WJ, Morris LE, Stroube R, Tagnon I, Fraumeni JF. Lung and laryngeal cancers in relation to shipyard employment in coastal Virginia. J Natl Cancer Inst 1980;65:571-5.

12 Gottlieb MS. Lung cancer and the petroleum industry in Louisiana. J Occup Med 1980;22:384-8.

13 Benhamou S, Benhamou E, Flamant R. Occupational risk factors of lung cancer in a French case-control study. $\mathrm{Br} J$ Ind Med 1988;45:231-3.

14 Rinsky RA, Meluis JM, Hornung RW, et al. Case-control study of lung cancer in civilian employees at the Portsmouth naval shipyard, Kittery, Maine. Am J Epidemiol 1988;127:55-64.

15 Hull CJ, Doyle E, Peters JM, Garabrant DH, Bernstein L, Preston-Martin S. Case-control study of lung cancer in Los Angeles county welders. Am J Ind Med 1989;16:103-12.

16 Menck HR, Henderson BE. Occupational differences in rates of lung cancer. J Occup Med 1976;18:797-801.

17 Milham S. Cancer mortality patterns associated with exposure to metals. In: Saffiotti U, Wagoner JK, eds. Occupational carcinogenesis. Ann NY Acad Sci 1976;271:243-9.

18 Office of Population Censuses and Surveys. Occupational mortality, 1970-1972. England and Wales. Decennial supplement. London: HMSO, 1978.

19 Redmond CK, Wieand HS, Rockette HE, Sass R, Weinberg G. Long term mortality experience of steel workers. Update for NIOSH contract. Cincinnati: National Institute for Occupational Safety and Health, 1979. (No HSM 99-71-32.)

20 Beaumont BJ, Weiss NS. Mortality of welders, shipfitters, and other metal trades workers in boilermakers local no. 104 , AFL-CIO. Am J Epidemiol 1980;112:775-86.

21 Beaumont JJ, Weiss NS. Lung cancer among welders. $J$ Occup Med 1981;23:839-44.

22 Polednak AP. Mortality among welders, including a group exposed to nickel oxides. Arch Environ Health 1981;36: $235-42$.

23 Sjogren B, Malker $\mathrm{H}$. Chromium and asbestos as two probable risk factors in lung cancer among welders. $J$ Occup Med 1982;24:874-5.

24 Milham SJ. Occupational mortality in Washington State 19501974. Washington: US Department of Health and Human Services 1983. (NIOSH publ No 83-116.)

25 Becker N, Claude J, Frentzel-Beyme R. Cancer risk of arc welders exposed to fumes containing chromium and nickel. Scand $J$ Work Environ Health 1985;11:75-82.

26 Puntoni R, Vercelli M, Di Giorgio F, Valerio F, Bonassi S, Ceppi M, Santi L. Mortality study among autogenous and electrical welders in the port of Genoa (Italy). In: Stern RM, Berlin A, Fletcher AC, Järvisalo J, eds Health hazards and biological effects of welding fumes and gases. Amsterdam: Exerpta Medica, 1986, 469-72.

27 Sjogren B, Weiner J, Horte LG, Carstensen J. Mortality among Swedish welders and gas-cutters. In: Stern RM, Berlin A, Fletcher AC, Järvisalo J, eds. Health hazards and biological effects of welding fumes and gases. Amsterdam: Exerpta Medica, $1986,457-9$.

28 Sjogren B, Carstensen J. Cancer morbidity among Swedish welders and gas-cutters. In: Stern RM, Berlin A, Fletcher AC, Järvisalo J, eds. Health hazards and biological effects of welding fumes and gases. Amsterdam: Exerpta Medica, 1986, 461-3.

29 Tola S, Kalliomaki PL, Pukkala E, Asp S, Korkala ML. Incidence of cancer among welders, platers, machinists, and pipe fitters in shipyards and machine shops. Br J Ind Med 1988;45:209-18.

30 Merlo F, Costantini M, Doria M. Cause specific mortality among workers exposed to welding fumes and gases: a historical prospective study. In: International Conference on Industrial Health and the VIIIth UOEH International SymposiumHealth Surveillance of workers. Journal of the University of Occupational and Environmental Health, Japan 1989;Suppl 11:302-15.

31 Simonato L, Fletcher AC, Andersen A, et al. A historical prospective study of European stainless steel, mild steel, and shipyard welders. Br J Ind Med 1991;48:145-54.
32 Breslow L, Hoaglin L, Rasmussen G, Abrams HK. Occupations and cigarette smoking as factor in lung cancer. Am J Public Health 1954;44:171-81.

33 Gerin M, Siemiatycki G, Richardson L, Pellerin J, Lakhani R, Dewar R. Nickel and cancer associations from a multicancer occupation exposure case-referent study: preliminary findings. In: Sunderman FW, ed. Nickel in the human environment. Lyon: International Agency for Research on Cancer, 1984; 105-15. (Sci Publ No 53.)

34 Buiatti E, Kriebel D, Geddes M, Santucci M, Pucci N. A case control study of lung cancer in Florence, Italy. I Occupational risk factors. J Epidemiol Community Health 1985;39:244-50.

35 Schoenberg JB, Stemhagen A, Mason TJ, Patterson J, Bill J, Altman R. Occupation and lung cancer risk among New Jersey white males. J Natl Cancer Inst 1987;79:13-21.

36 Lerchen ML, Wiggins CL, Samet JM. Lung cancer and occupation in New Mexico. J Natl Cancer Inst 1987;79: 639-45.

37 Puntoni R, Vercelli M, Merlo F, Valerio F, Santi L. Mortality among shipyard workers in Genoa, Italy. Ann NY Acad Sci 1979;330:353-77.

38 Sjogren B. A retrospective cohort study of mortality among stainless steel welders. Scand J Work Environ Health 1980;6:197-200.

39 Silverstein M, Maizlish N, Park R, Mirer F. Mortality among workers exposed to coal tar pitch volatiles and welding emissions: an exercise in epidemiologic triage. Am J Public Health 1985;75:1283-7.

40 Melkild A, Langard S, Andersen A, Stray Tonnesen JN. Incidence of cancer among welders and other workers in a Norwegian shipyard. Scand J Work Environ Health 1989; 15:387-94.

41 Sjogren B, Gustavsson A, Hedstrom L. Mortality in two cohorts of welders exposed to high and low-levels of hexavalent chromium Scand J Work Environ Health 1987;13:247-51.

42 Dunn JE, Weir JM. A prospective study of mortality of several occupational groups. Special emphasis on lung cancer. Arch Environ Health 1968;17:71-6.

43 McMillan GHG, Pethybridge RJ. The health of welders in Naval Dockyards: proportional mortality study of welders and two control groups. J Soc Occup Med 1983;33:75-84.

44 Milne KL, Sandler DP, Everson RB, Brown SM. Lung cancer and occupation in Alameda county: a death certificate casecontrol study. Am J Ind Med 1983;4:565-75.

45 Newhouse ML, Oakes D, Woolley AJ. Mortality of welders and other craftsmen at a shipyard in NE England. Br J Ind Med 1985;42:406-10.

46 Kjuus H, Skjaerven R, Langard S, Lien JT, Aamodt T. A casereferent study of lung cancer, occupational exposures and smoking. Scand J Work Environ Health 1986;12:193-202.

47 Peto J. Cancer morbidity and mortality studies of welders. In: Stern RM, Berlin A, Fletcher AC, Järvisala J, eds. Health hazards and biological effects of welding fumes and gases. Amsterdam: Exerpta Medica, 1986:423-34.

48 Dunn JE, Linden G, Breslow L. Lung cancer mortality experience of men in certain occupations in California. $\mathrm{Am} \mathrm{J}$ Public Health 1960;50:1475-87.

49 Sterling TD, Weinkam JJ. Smoking characteristics by type of employment. J Occup Med 1976;18:743-54.

50 Breslow NE, Day NE. Statistical methods in cancer research: The design and analysis of cohort studies. Vol II. Lyon: International Agency for Research on Cancer 1987. (Sci Publ No 82.)

51 Coleman M, Douglas A, Hermon C, Peto J. Cohort study analysis with a FORTRAN computer program. Int $J$ Epidemiol 1986;15:134-7.

52 Baker RJ, Nelder JA. The GLIM system: Release 3. Oxford: Numerical Algorithms Group, 1978.

53 EGRET. Reference manual. Seattle, WA: Statistics and Epidemiology Research Corporation, 1990.

54 Axelson $\mathrm{O}$. Aspects on confounding in occupational health epidemiology. Scand J Work Environ Health 1978;4:85-9.

55 Moulin JJ. Les études épidémiologiques de cohorts industrielles: comment prendre en compte le tabagisme? Arch Mal Prof 1991;52:319-26.

56 Surgeon General. The health consequences of smoking: cancer. Washington: US Dept of Health and Human Services, Office on Smoking and Health, 1982.

57 Selikoff IJ, Seldman H, Hammond EC. Mortality effects of cigarette smoking among amosite asbestos factory workers. $J$ Natl Cancer Inst 1980;65:507-13.

Accepted 20 June 1992 